\title{
Students' Perceived Service Quality of Distance Learning Courses in a Dual-Mode Education System
}

\author{
Dursun Yener \\ Beykoz Vocational School of Logistics, Turkey
}

\begin{abstract}
Distance learning (DL) has become an important part of university education. In the past DL was applied in different universities with different forms. With rapid technological developments, DL gained a new format through the Internet. Students can take courses online wherever they are geographically. Therefore, working people and adults can enroll higher education institutions without time and space barriers. Like many countries, Turkey adapted its education system to this new form. From 1980's to recent years, this system has been applied through open education faculties in state universities. However as the number of foundation universities increase, DL became more common in various programs at different levels. Conventional universities use this system in some courses so students take both face-to-face and online courses together. Universities can use this system to use their scarce financial resources effectively with saving some costs and provides possibilities for sustainable advantage. In this paper, evaluation of students', who are enrolled in a traditional university, about DL quality was analyzed using Grönross' service quality model.
\end{abstract}

Keywords: Distance learning, Grönross, Perceived service quality, Dual-mode education

\section{Introduction}

Higher education around the world has experienced rapid growth. New players in the higher education market are adopting sophisticated marketing techniques to persuade students to enroll to their institutions (Beneke, 2001). Kotler and Fox (1995) offer a description for marketing in education sector as "analysis, planning, implementation, and control of carefully formulated programmes designed to bring about voluntary exchanges of value with target markets to achieve institutional objectives.

Distance learning (DL) is closely associated with the new information technologies that have a significant impact on university studies (Gedviliene, 2010). Besides online colleges, there are many traditional higher education institutions that offer their students both face-to-face and online courses together. This dual-mode system provides flexibility particularly for working students (Ruth and Conners, 2012; Wu and Hwang, 2010). Students' retention and their performance are influenced by the service quality provided by the higher education institutions (Kwek, Lau and Tan, 2010). Education quality is a complicated phenomenon influenced by different factors (Targamadze et al., 2010). The numbers of studies about quality on DL is increasing, but only a few have examined the quality of e-learning from the learner's perspective (Jung, 2011, p.445). 


\section{Literature Review}

\section{Distance Learning}

DL is defined as "the acquisition of knowledge and skills through mediated information and instruction" (US Distance Learning Association, 2012). It is a type of educational mode that allows for flexibility in terms of mode and delivery. Learning content is delivered through electronic technologies (Guha and Maji, 2008) such as internet, audio or video, interactive TV, CD-ROM, and so on. If there is a geographical separation between student and provider, DL will be an effective solution for both parts (Akeusola et al., 2011). DL is not new to education; correspondence schools have operated in the US institutions such as Pennsylvania State University which is one of the first universities that had a program of correspondence study in 1892 (Banas and Emor, 1998). Today distance education exists worldwide and is applied to education at different levels (Sizoo et al., 2003).

With the rapid growth of the Internet, DL has become a viable form of education (Granitz and Greene, 2003). The global e-learning market is predicted to reach $\$ 107.3$ billion by the year 2015. The US and Europe have $70 \%$ of market share of this market. Asia-Pacific region has the fastest growing market with $20 \%$ growth rate annually (Jose, 2010). The rising popularity of elearning is attributed to its ability to enable students to study without the constraints of time and space (Tseng et al., 2011). DL extends geographical boundaries for students (Sheeja, 2011); the students can access to the online course at any time wherever they are with any type of Internet-capable device. Universities can increase enrollment numbers, decrease the number of extra-hire teachers and offer a more flexible schedule to people with DL (Borstorff and Lowe, 2007). DL courses mean a reduced burden on university facilities (Ruth and Conners, 2012) and reduce overhead costs such as dormitories, classrooms and library shelf space associated with traditional delivery (Banas and Emor, 1998).

Although DL has many benefits for all stakeholders, there are some disadvantages for students and instructors. With the lack of human contact and personal instruction, students feel themselves isolated and DL can seem cold and impersonal (Borstorff and Lowe, 2007). Another negative implication of e-learning is information overload which causes learning time increase and learning motivation decreases. Course completion rates in distance education courses are often lower than in traditional classes (Ruth and Conners, 2012).

In evaluation of effectiveness of DL, researchers focus on different aspects, such as technology and human factor in e-learning system (Wu and Hwang, 2010). Studies have identified five primary aspects in evaluating e-learning effectiveness. These include; quality of the system, learner attractiveness, instructor attitudes, service quality, supportive issues. Lin (2010) developed a fuzzy evaluation model (Tseng et al., 2011) with four aspects which are; system quality, information quality, service quality, web site quality factors. In his comprehensive elearning solution model, Henry (2001) refers to the three parts of e-learning as technology, content and service (Wong and Huang, 2011). Various models have different dimensions to evaluate the effectiveness of $\mathrm{DL}$, but all emphasize the importance of service quality.

\section{Service Quality and DL}

A service is any act or performance one party can offer to another that is essentially intangible and does not result in the ownership of anything. Its production may or may not be tied to a 
physical product (Kotler and Keller, 2012). Parasuraman, Zeithaml and Berry (1988) emphasize that knowledge about goods' quality is insufficient to understand service quality due to characteristics of services namely intangibility, heterogeneity, inseparability and perishability. According to Oldfield and Baron (2000), higher education can be seen as a pure service and educational services fall into the field of services marketing (Gruber et al., 2010).

Service quality is defined as the result of the comparison that customers make between expectations about a service and perception of the way the service was delivered (Grönross, 1984). The term "quality in education" has been defined by various scholars as excellence in education, value addition in education or defect avoidance in education process (Kwek, Lau, and Tan, 2010). Quality in DL is defined as an evaluation process that "judges, measures, or assesses the quality of the development and delivery of online courses/learning environments focused on appropriate design and best practice, and is aimed at self-improvement ensuring quality instruction in a non-threatening way" (Quilter and Weber, 2004; Chapman and Henderson, 2010). DL quality is a complex and multi-faceted issue. There are general quality principles that can apply both conventional learning and DL; however DL has unique characteristics such as asynchronous interactions and open access to resources (Jung, 2011). Quality in DL can have different meanings for institutions and researchers. Institutions may be more concerned about quality of their management and researchers may be more interested in the nature, depth and extent of the learning (Jung and Latchem, 2007).

Measuring quality has always been an important issue, and a limited number of studies addressed this problem (Chapman and Henderson, 2010). In literature there are two popular models used widely to measure service quality. Academics divided into two schools of thought either; Nordic or American (Kang and James, 2004).

The American perspective of service quality is based primarily on Parasuraman et al.'s proposed "Gaps model", also known as SERVQUAL, which only reflects the service delivery process. It has five components which are reliability, assurance, tangibles, responsiveness, and empathy (Parasuraman et al., 1988). The SERVQUAL model is frequently used to evaluate the students' perceived service quality in the education industry.

Grönross (1984), based on the Nordic perspective, introduced the "perceived service quality model" which has three dimensions; technical quality, functional quality and image (Kang and James, 2004). Technical quality answers the question what the customer gets. Functional quality answers the question of how he/she gets it. Functional quality cannot be evaluated as objectively as the technical dimension. The organization's image works as a filter and can positively or negatively modify the customers' perception of service quality. The expectations of consumers are influenced by their view about company and its image so corporate image or brand image will be an important dimension of perceived service quality (Grönross, 1984). Marketing researchers suggested brand image is a vital element of brand equity. Keller (1993) defined brand image as "a set of perceptions about a brand as reflected by brand associations in consumer's memory". Aaker (1991) defined it as "a set of associations, usually organized in some meaningful way". However, Biel (1992) defined it as "a cluster of attributes and associations that consumers connect to the brand name". The more positive brand image is positively related to higher brand equity (Faircloth et al., 2001).

As all companies, higher education institutions which hold a favorable image by the public would definitely gain a better position in the market, sustainable competitive advantage and increase market share (Sondoh et al., 2007). University image can be defined as the sum of all 
the beliefs an individual has towards the university. According to Kotler and Fox (1995), an institution's current image is often more important than quality because perceived image actually influences choices made by prospective students (Alves and Raposo, 2010). McNally and Speak (2002) define a higher education brand as "perception or emotion maintained by a buyer or a prospective buyer describing the experience related to doing business with an academic institution with its product and service". Like many service-oriented organizations, universities are facing an increasingly competitive environment in which they must find ways to differentiate their institution (Judson et al., 2009).

\section{DL in the World and Turkey}

DL has become increasingly popular over the years. In the 2000-2001 academic year, more than three million students enrolled in DL courses in USA, and the National Center for Education Statistics expects this number to increase 18.2 million by 2013 (Güneş and Altıntaş, 2012; NCES, 2012). In 2000-2001, 89\% of 4-year public institutions in the USA offered distance education courses with $90 \%$ of the offerings being internet courses using computer-based instruction (Wang et al., 2010). From the 1970s onwards, Asian governments established open universities to accommodate the large numbers of adults and school-leavers unable to gain entry to conventional universities. Thailand was the first country to start an open admissions university in 1971 and the following years, open universities were established in many Asian countries such as Israel, Iran, Turkey, India, China, Japan, Hong Kong etc (Jung and Latchem, 2007).

By the end of 2011, the population of Turkey is 72,74 million and its population growth rate is 1,35 percent yearly. The median age is 29,7 , so majority of Turkey's population is young. The ages of students in higher education institutions are usually between 19-30. 12,52 million people which means that $16,77 \%$ of the total population is between these age groups (www.tuik.gov.tr).

In spite of the high percentage of young population, the number of higher education institutions is not sufficient. There are 103 public universities whereas 65 foundation universities and 7 foundations' vocational school (www.yok.gov.tr). The total number of the higher education institutions is 188 and their distribution can be seen in the Table 1.

Table 1. Number of Higher Education Institutions in Turkey

\begin{tabular}{|l|r|}
\hline Type of Institutions & Number \\
\hline State Universities & 103 \\
\hline Foundation Universities & 65 \\
\hline Other Institutions & 13 \\
\hline Foundation Vocational School & 7 \\
\hline Total & 188 \\
\hline
\end{tabular}

In Table 2 it is shown the total number of students in higher education institutions at different education levels with respect to open and traditional education system in 2012. Approximately $45 \%$ of the total students were enrolled in open education institutions in Turkey, mainly at Anadolu University. 
Table 2. The Number of Students in Higher Education Institutions in Turkey in 2012

\begin{tabular}{|l|r|r|r|r|r|}
\hline & \multicolumn{2}{|l|}{ Open Education } & \multicolumn{2}{l}{ Traditional Education } & \multirow{2}{*}{ Total } \\
\cline { 2 - 5 } & Number & \multicolumn{1}{l}{$\%$} & Number & \multicolumn{1}{c|}{$\%$} & \\
\hline Pre-graduate & 586.233 & 46,15 & 684.118 & 53,85 & 1.270 .351 \\
\hline Undergraduate & 1.365 .261 & 48,03 & 1.477 .075 & 51,97 & 2.842 .336 \\
\hline Graduate & 0 & 0 & 220.970 & 100,00 & 220.970 \\
\hline Total & 1.951 .494 & 45,03 & 2.382 .163 & 54,97 & 4.333 .657 \\
\hline
\end{tabular}

In Turkey, the first Open Education Faculty was established by Anadolu University in 1982. By 2012, Istanbul University and Atatürk Univertiy, which are both state universitites, started to accept students to their open education faculties.

After establishing the foundation higher education institutions, the numbers of DL programs rapidly increased. Today most of the state universitites have DL programs too, or are prepared to initiate. Table 3 presents the numbers of higher education institutions which have at least one DL program at different levels. For example 26 state and 6 foundation institutions have DL programs and totally 36 different programs in DL exist in 2-years vocational schools.

Table 3. Number of Higher Education Institutions That Have DL Programs

\begin{tabular}{|l|c|c|c|c|}
\hline & State & Foundation & Other & $\begin{array}{c}\text { No. of Programs } \\
\text { in DL }\end{array}$ \\
\hline Pre-graduate & 26 & 6 & 1 & 36 \\
\hline Undergraduate & 6 & 4 & 1 & 22 \\
\hline Graduate & 5 & 8 & 1 & 13 \\
\hline
\end{tabular}

\section{Methodology}

To measure service quality, Grönross Service Quality Model was used. This model is more appropriate for representation of service quality than the SERVQUAL perspective, which concentrates only on functional quality (Kang and James, 2004). Research model is represented below in Figure 1.

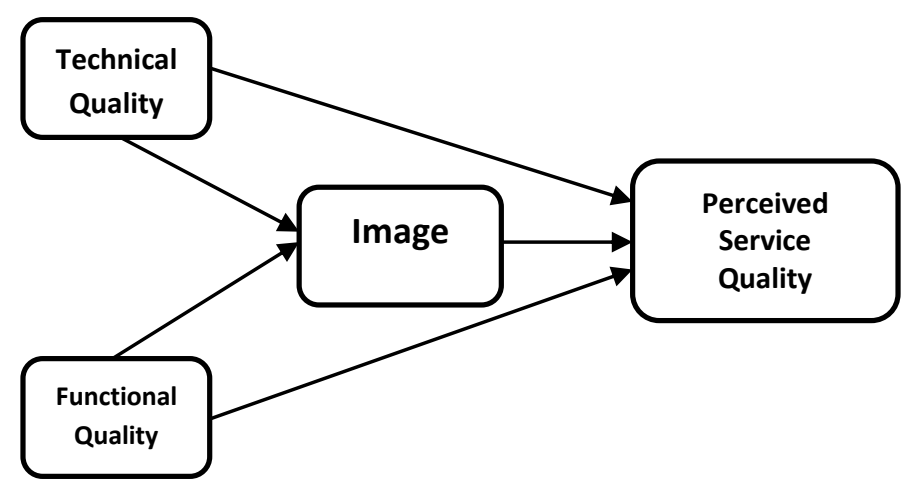

Figure 1. Research Model 
Based on the model above, there are two research hypotheses tested in this study. They are the following:

$\mathbf{H}_{\mathrm{A}}$ : Functional quality and technical quality have significant effect on image of students, who take both traditional and DL courses, about DL education.

$\mathbf{H}_{\mathrm{B}}$ : Functional quality, technical quality, and image of DL education have significant effect on perceived service quality of students who take both traditional and DL courses.

\section{Participants}

Beykoz Vocational School of Logistics (BVSoL), one of the foundation vocational schools, was founded by the Turkish Logistics Research and Education Foundation (TURLEV) in 2008 (www.beykoz.edu.tr). In 2012-2013, BVSoL started to apply dual education mode. Its students take one elective course through DL system in their $3^{\text {rd }}$ and $4^{\text {th }}$ semesters. All participants in the research are enrolled to BVSoL and they are in the $3^{\text {rd }}$ semester. Convenience sampling method was used and participation was voluntary. The survey was conducted anonymously and no personal information was collected that could be used to identify any individual. Sample size of the research is 377 students. In the table below, their distribution can be seen according to enrolled programs.

Table 4. Number of Participants According to Enrolled Programs

\begin{tabular}{|l|c|c|c|}
\hline Program & $\begin{array}{c}\text { Total number of } \\
\text { enrolled students }\end{array}$ & $\begin{array}{c}\text { Participation } \\
\text { number }\end{array}$ & Participation \% \\
\hline Logistics & 259 & 147 & 56,8 \\
\hline Foreign Trade & 98 & 63 & 64,3 \\
\hline Computer Programming & 88 & 26 & 29,5 \\
\hline Maritime and Port Management & 53 & 30 & 56,6 \\
\hline Civil Aviation Management & 52 & 34 & 65,4 \\
\hline Public Relations & 52 & 24 & 46,2 \\
\hline Business Management & 42 & 25 & 59,5 \\
\hline Energy Facilities Management & 37 & 19 & 51,4 \\
\hline Applied English Translation & 15 & 9 & 60,0 \\
\hline Total & $\mathbf{6 9 6}$ & $\mathbf{3 7 7}$ & $\mathbf{5 4 , 2}$ \\
\hline
\end{tabular}

It appears that half of the students in the school participated in the study. Of the participants, majority enrolled the programs of Logistics and Foreign Trade, whereas only few students enrolled the English Translation program.

Demographic characteristics of the participants are shown in Table 5. According to the figures, $57 \%$ of were male and $43 \%$ were female. Age ranged from 19 to 22 . Approximately one third of participants work either part time or full time. A big majority had intermediate or advanced computer experiences. 
Table 5. Demographic Characteristics of Participants

\begin{tabular}{|l|l|l|l|l|}
\hline Gender & Male: \%56,5 & Female: \%43,5 & & \\
\hline Age & $19: \% 20,4$ & 20: \%30,8 & $21: \% 28,4$ & 22: \%10,3 \\
\hline Working & Full-time: \%7,7 & Part-time: \%21 & & \\
\hline $\begin{array}{l}\text { Monthly } \\
\text { Income (TL) }\end{array}$ & $0-500: \% 38,9$ & $5001-1000: \% 36,1$ & $1001-1500: \% 11,1$ & $1501+: \% 13,9$ \\
\hline $\begin{array}{l}\text { Computer } \\
\text { expertise }\end{array}$ & Few: \%4,5 & Medium: \%27,6 & Intermediate: \%47,5 & Advanced: \%20,4 \\
\hline $\begin{array}{l}\text { Connection } \\
\text { to DL }\end{array}$ & Home: \%90,2 & Work: \%3,4 & School: \%1,6 & Other: \%4,8 \\
\hline $\begin{array}{l}\text { Connection } \\
\text { to DL in a } \\
\text { week }\end{array}$ & $0: \% 24,7$ & $1: \% 45,6$ & $2: \% 21$ & $3+: \% 8,8$ \\
\hline
\end{tabular}

In BVSoL, there are four alternative courses for students to take in the DL system as an elective course. These are Entrepreneurship, Customer Relationship Management, Research Methods and Logistics. There is no quota for students and the distribution of research participants according to their elective courses is shown in Table 6 . The number of students who select Logistics course is lower than other courses because it is a core course for some programs such as Logistics Management, Business Administration, etc.

Table 6. Distribution of Participants According to Selected DL Courses

\begin{tabular}{|l|r|r|}
\hline Courses & Frequency & Percent \\
\hline Entrepreneurship & 175 & 46,40 \\
\hline Customer Relations Management & 175 & 46,40 \\
\hline Research Methods & 18 & 4,80 \\
\hline Logistics & 9 & 2,40 \\
\hline Total & 377 & 100 \\
\hline
\end{tabular}

\section{Data Gathering Instrument}

Data were obtained by conducting a questionnaire which contained close-ended questions. The questionnaire had two parts. First was perceived service quality scale which covered 34 closed-ended questions prepared by the researcher with respect to factors in Grönross' service quality model. The second part of the questionnaire included questions about participants' demographic characteristics and courses they took in the DL system.

Overall reliability and factor analysis values for the data gathering instrument were high and sufficient. As seen in Table 7, KMO results for all factors are greater than 0,6 and it means the sample size is adequate for factor analysis (Pallant, 2005). Significance value of Bartlett test is lower than $0,05(0,00)$, therefore factor analysis is appropriate. Internal reliability of the factors is calculated with Cronbach's alpha test. It is expected the alpha value is greater than 0,70 (Nunnally, 1978), and the obtained alpha value for the instrument used in this study is 0,865 , which is relatively high. It can be safely said that all variables have met the required conditions for factor analysis. 
Table 7. Factor Analysis and Reliability Statistics

\begin{tabular}{|l|r|r|r|r|r|c|}
\hline Factor Name & $\begin{array}{r}\text { Number } \\
\text { of Items }\end{array}$ & $\begin{array}{r}\text { Total } \\
\text { Variance } \\
\text { Explained }\end{array}$ & KMO & Bartlett & Reliability & Reliability \\
\cline { 1 - 3 } Functional Quality & 13 & 29,45 & 0,838 & 0,000 & 0,794 & \multirow{2}{*}{0,865} \\
\hline Technical Quality & 9 & 31,37 & 0,794 & 0,000 & 0,714 & \multirow{2}{*}{ Image } \\
\hline
\end{tabular}

Table 8. Service Quality Factor Analysis

\begin{tabular}{|l|c|c|c|c|c|}
\hline & Factor Loading & \% of Variance & KMO & Bartlett & Reliability \\
\cline { 1 - 2 } Q1 & 0,918 & & & & \\
\cline { 1 - 2 } Q2 & 0,916 & \multirow{2}{*}{$68,70 \%$} & 0,765 & 0,000 & 0,843 \\
\cline { 1 - 2 } Q3 & 0,848 & & & & \\
\hline
\end{tabular}

In Table 8, the results of the factor analysis for service quality perception, for this factor, there are four items (shown as Q1,....Q4) which explain \% 68,7 of the factor. Reliability analysis (cronbach alfa) and other statistics have sufficient values for further statistical analysis.

In Table 9, mean and standard deviation values of the factors in the research model are seen. The results show that technical quality perceptions of students about DL are greater than their functional quality perceptions.

Table 9. Descriptive Statistics of Factors

\begin{tabular}{|l|c|c|}
\hline Factor Name & Mean & Std. Dev. \\
\hline Functional Quality & 2,84 & 0,62 \\
\hline Technical Quality & 3,09 & 0,62 \\
\hline Image & 3,27 & 0,74 \\
\hline
\end{tabular}

The mean value of the image factor is 3,27 , which is greater than functional and technical quality perceptions of the students against DL system. It is because the image of the higher education institution is not only depend on its DL system.

\section{Findings}

\section{Correlation and Regression Analyses}

In Table 10, correlation analyses between factors in Grönross service quality models are seen. According to the results, all factors have significant and positive relationships with each other. Functional and technical quality factors have higher correlation with perceived service quality than image factor. Thus, research hypotheses $\mathrm{H}_{A}$ and $\mathrm{H}_{B}$ can not be rejected. 
Multiple regressions are used to explore the relationship between one continuous dependent variable and a number of independent variables or predictors (Pallant, 2005). To assess the statistical significance of the result, ANOVA value should be analyzed. This value tests the null hypothesis that multiple $R$ in the population equals to 0 . The model in this example reaches statistical significance $($ sig. $=0,000)$. If there is a correlation between independent variables, multicollinearity exists. If the VIF (variance inflation factor) value is above 10 , it indicates multicollinearity (Pallant, 2005).

Table 10. Correlation Analysis

\begin{tabular}{|c|c|c|c|c|c|}
\hline & & $\begin{array}{l}\text { Functional } \\
\text { Quality }\end{array}$ & $\begin{array}{l}\text { Technical } \\
\text { Quality }\end{array}$ & Image & $\begin{array}{l}\text { Service } \\
\text { Quality }\end{array}$ \\
\hline \multirow{3}{*}{$\begin{array}{l}\text { Functional } \\
\text { Quality }\end{array}$} & Pearson Correlation & 1 & ,688 & 170 & ,544 \\
\hline & Sig. (2-tailed) & & 0,000 & 0,002 & 0,000 \\
\hline & $\mathrm{N}$ & 340 & 319 & 317 & 340 \\
\hline \multirow{3}{*}{$\begin{array}{l}\text { Technical } \\
\text { Quality }\end{array}$} & Pearson Correlation & ,688 & 1 & ,265 & ,571 \\
\hline & Sig. (2-tailed) & 0,000 & & 0,000 & 0,000 \\
\hline & $\mathrm{N}$ & 319 & 349 & 329 & 349 \\
\hline \multirow{3}{*}{ Image } & Pearson Correlation & ,170 & ,265 & 1 & ,275 \\
\hline & Sig. (2-tailed) & 0,002 & 0,000 & & 0,000 \\
\hline & $\mathrm{N}$ & 317 & 329 & 352 & 352 \\
\hline \multirow{3}{*}{$\begin{array}{l}\text { Service } \\
\text { Quality }\end{array}$} & Pearson Correlation & ,544 & ,571 & ,275 & 1 \\
\hline & Sig. (2-tailed) & 0,000 & 0,000 & 0,000 & \\
\hline & $\mathrm{N}$ & 340 & 349 & 352 & 377 \\
\hline
\end{tabular}

In the Table 11, VIF values of independent variables are not higher than 10 , so it is concluded that there is no multicollinearity. $R^{2}$ value shows how much the dependent variable is explained by the model. If the $R^{2}$ value is greater than 0,5 value it is accepted that explanation level of the model is high.

Table 11. Service Quality Regression Analysis

\begin{tabular}{lllll}
\hline Dependent variable & \multicolumn{2}{l}{ Service Quality } & & \\
Independent variables & Beta & t value & $\boldsymbol{p}$ value & VIF value \\
Functional quality & 0,321 & 5,131 & 0,000 & 1,952 \\
Technical quality & 0,308 & 4,856 & 0,000 & 2,008 \\
Image & 0,155 & 3,351 & 0,001 & 1,071 \\
& & & & \\
& & & $\mathbf{R}=\mathbf{0 , 6 3 6}$ & $\mathbf{R}^{\mathbf{2}}=\mathbf{0 , 4 0 4}$ \\
\hline
\end{tabular}

ANOVA test result $(0,000)$ shows that the model has statistical significance. There are three independent variables that explain service quality. These are functional quality, technical quality, and image. VIF values are under 10 and there is no multicollinearity between independent variables. $R^{2}$ value is $\% 40,4$. 
All factors have positive correlations with service quality. As functional and technical quality level increase, service quality of DL increase with values of $\% 32,1$ and $\% 30,8$ respectively. Image factor has also positive correlation, however its effect is less $(\% 15,5)$ than the other two independent factors.

According to findings reported in Table 12 , ANOVA test result $(0,000)$ shows that the model has statistical significance. There is only one independent variable that explains image that is technical quality. Since $p$-value of the functional quality has greater than $0,05(0,643)$, there is no significant correlation with image. VIF value of technical quality is 1,951 so there is no multicollinearity between independent variables. $\mathrm{R}^{2}$ value is $\% 6,7$. Technical quality has little effect on image, because image is affected from many different factors such as advertisements, past experiences and reference groups.

Table 12. Image Regression Analysis

\begin{tabular}{lllll}
\hline Dependent variable & Image & & & \\
Independent variables & Beta & $\mathbf{t}$ value & $\mathbf{p}$ value & VIF value \\
Functional quality & 0,036 & 0,464 & 0,643 & 1,951 \\
Technical quality & 0,231 & 2,960 & 0,003 & 1,951 \\
& & & $\mathbf{R}=\mathbf{0 , 2 5 8}$ & $\mathbf{R}^{\mathbf{2}}=\mathbf{0 , 0 6 7}$ \\
\hline
\end{tabular}

The study also tested demographics-related hypotheses in terms of gender, working status, connection to $\mathrm{DL}$, programs enrolled, selected DL course etc. The results of the corresponding statistical tests were presented separately below.

$\mathrm{H}_{1}$ : There is a significant relationship between the perceived images of students according to gender.

Table 13. Independent Sample t-test

\begin{tabular}{|l|l|l|l|l|l|l|l|}
\hline \multicolumn{2}{|c|}{} & \multicolumn{2}{l|}{$\begin{array}{l}\text { Levene's Test for } \\
\text { Equality of } \\
\text { Variances }\end{array}$} & \multicolumn{3}{|l|}{ t-test for Equality of Means } \\
\cline { 3 - 9 } & & F & Sig. & t & df & $\begin{array}{l}\text { Sig. (2- } \\
\text { tailed) }\end{array}$ \\
\hline \multirow{2}{*}{ Image } & Equal variances assumed & 0,097 & 0,756 & $-2,157$ & 350 & 0,032 \\
\cline { 2 - 9 } & Equal variances not assumed & & & $-2,157$ & 329,311 & 0,032 \\
\hline
\end{tabular}

Since the significance level is less than $0,05(0,032), \mathrm{H}_{0}$ cannot be rejected. Perceived image level of students differ according to their gender and female students have higher image level $\left(\mu_{\text {male }}=3,20, \mu_{\text {female }}=3,37\right)$

$\mathrm{H}_{2}$ : There is a significant relationship between perceived functional quality according to working status of participants. 
Table 14. Independent Sample t-test

\begin{tabular}{|c|c|c|c|c|c|c|}
\hline & & \multicolumn{2}{|c|}{$\begin{array}{l}\text { Levene's Test for } \\
\text { Equality of } \\
\text { Variances }\end{array}$} & \multicolumn{3}{|c|}{ t-test for Equality of Means } \\
\hline & & $\mathrm{F}$ & Sig. & $\mathrm{t}$ & $\mathrm{df}$ & Sig. (2-tailed) \\
\hline \multirow{2}{*}{$\begin{array}{l}\text { Functional } \\
\text { Quality }\end{array}$} & $\begin{array}{l}\text { Equal variances } \\
\text { assumed }\end{array}$ & 6,473 & 0,013 & 2,028 & 95 & 0,045 \\
\hline & $\begin{array}{l}\text { Equal variances not } \\
\text { assumed }\end{array}$ & & & 2,395 & 64,401 & 0,020 \\
\hline
\end{tabular}

According to test results, students' working status affects their perceived functional quality. Student who work in a part-time job have higher perception than students who work in a full time job $\left(\mu_{\text {parttime }}=2,91, \mu_{\text {fulltime }}=2,59\right)$

$\mathrm{H}_{3}$ : There is a significant relationship between functional quality, technical quality, images, and perceived service quality of students according to connection place to $\mathrm{DL}$.

Table 15. ANOVA Test

\begin{tabular}{|c|c|c|c|c|c|c|}
\hline & & Sum of Squares & df & Mean Square & $\mathrm{F}$ & Sig. \\
\hline \multirow{3}{*}{$\begin{array}{l}\text { Functional } \\
\text { Quality }\end{array}$} & Between Groups & 14,848 & 3 & 4,949 & 5,13 & 0,002 \\
\hline & Within Groups & 324,152 & 336 & 0,965 & & \\
\hline & Total & 339 & 339 & & & \\
\hline \multirow{3}{*}{ Technical Quality } & Between Groups & 19,759 & 3 & 6,586 & 6,923 & 0,000 \\
\hline & Within Groups & 328,241 & 345 & 0,951 & & \\
\hline & Total & 348 & 348 & & & \\
\hline \multirow{3}{*}{ Image } & Between Groups & 12,994 & 3 & 4,331 & 4,459 & 0,004 \\
\hline & Within Groups & 338,006 & 348 & 0,971 & & \\
\hline & Total & 351 & 351 & & & \\
\hline \multirow{3}{*}{ Service Quality } & Between Groups & 16,082 & 3 & 5,361 & 5,556 & 0,001 \\
\hline & Within Groups & 359,918 & 373 & 0,965 & & \\
\hline & Total & 376 & 376 & & & \\
\hline
\end{tabular}

For all factors, there are significant differences between student groups with respect to connection place to DL course. According to the result of the post-hoc tests, students who connect to DL system at home have the highest functional and technical quality, image and perceived service quality perceptions. The second group is the students who connect to DL system at work.

$\mathrm{H}_{4}$ : There is a significant relationship between functional quality, technical quality, and service quality of students according to enrolled program. 
Table 16. ANOVA Test

\begin{tabular}{|l|l|r|r|r|c|c|}
\hline \multicolumn{2}{|c|}{} & Sum of Squares & df & Mean Square & F & Sig. \\
\hline \multirow{2}{*}{$\begin{array}{l}\text { Functional } \\
\text { Quality }\end{array}$} & Between Groups & 15,371 & 8 & 1,921 & 1,965 & 0,050 \\
& Within Groups & 323,629 & 331 & 0,978 & & \\
\hline \multirow{2}{*}{ Technical } & Total & 339 & 339 & & & \\
Quality & Between Groups & 21,595 & 8 & 2,699 & 2,812 & 0,005 \\
& Within Groups & 326,405 & 340 & 0,96 & \\
Service & Total & 348 & 348 & & & \\
Quality & Between Groups & 18,841 & 8 & 2,355 & 2,427 & 0,014 \\
& Within Groups & 357,159 & 368 & 0,971 & & \\
\hline
\end{tabular}

Functional quality perception was higher among students in Maritime and Port Management as well as Public Relations programs $\left(\mu_{\text {maritime }}=3,11 ; \mu_{\text {publicrelations }}=3,08\right)$. For technical quality perception; Maritime and Port Management and Applied Translation Programs ( $\mu_{\text {maritime }}=3,48$; $\mu_{\text {appliedtranslation }}=3,35$ ) had higher scores, and finally perceived service quality of Public Relations and Computer Programming students $\left(\mu_{\text {publicrelations }}=3,30 ; \mu_{\text {computer }}=3,36\right)$ were higher than the scores of students in other programs.

$\mathrm{H}_{5}$ : There is a significant relationship between perceived images of students according to selected course in DL.

Table 17. ANOVA Test

\begin{tabular}{|l|l|l|l|l|l|l|}
\hline \multicolumn{2}{|c|}{} & Sum of Squares & df & Mean Square & F & Sig. \\
\hline \multirow{4}{*}{ Image } & Between Groups & 8,526 & 3 & 2,842 & 2,888 & 0,036 \\
& Within Groups & 342,474 & 348 & 0,984 & & \\
& Total & 351 & 351 & & & \\
\hline
\end{tabular}

According to the ANOVA test results, there is a significant relationship between perceived images of students. Post-hoc tests show the difference so students who selected Research Methods have the highest perceived image level about the higher school institutions $\left(\mu_{\text {research }}=3,74\right)$. The second group comprised of students who selected Customer Relationship Management $\left(\mu_{\mathrm{CRM}}=3,31\right)$.

\section{Conclusion}

$\mathrm{DL}$ is an important issue in today's university education systems. With the developments in technology, DL became common and easily applicable for higher education institutions and students. For both parts DL have many advantages; universities does not suffer many costs that are relevant with traditional education such as classrooms and extra-hired teachers, on the other hand, students do not have to be present at school for the courses. If they have required hardware and software, they can easily access to all the course materials whereever they are, so they will have more time for working. Like many countries, universities in Turkey started to use DL system effectively. Even some universities use dual education sytem which 
combines DL and traditional education together. Students in this system can take courses in classroom or DL and will compare the effectiveness of the courses. The most significant measures of DL effectiveness were the quality of the DL system and learner attractiveness. In this article, evaluation of students about DL quality, who are enrolled in a traditional higher education institution, was analyzed using Grönross' service quality model.

According to the results of the study, technical and functional quality of DL and image of the institution have positive effect on students' perceived service quality. Since image of the higher education institution is affected by many different factors, its effect on perceived service quality is not so high as technical and functional quality of DL system. Students' technical quality perception about $\mathrm{DL}$ is more than functional quality perception. If the institution can enhance its technical and functional quality perception about distance learning system, students' service quality perception also enhance. However increase in image perception does not depend only on DL system and only some portion of the image raises perceived service quality about $\mathrm{DL}$. The expectations of students are influenced by their view about company (Grönross, 1984). The more positive brand image is positively related to higher brand equity (Faircloth et al., 2001).

In dual education mode, attitudes of students toward courses in DL are not positive. They thought they are more successful in the traditional courses than DL courses and do not believe $\mathrm{DL}$ courses are useful for their careers after school. In the questionnaire, items that have the least mean values are "I wish all my courses would be in DL" and "I recommend the DL courses to my friends". There are two reasons for those results. First, students feel the courses in DL impersonal and do not feel themselves as a student as Borstorff and Lowe (2007) emphasized. Second, many students do not have required hardware and software to access courses in DL, and believe that providing them is the responsibility of higher education institution. Enhanced usage of multimedia features can attract learner attention and may increase learner attractiveness. Reducing the waiting time for learning materials to load may improve the quality of the system (Ruth and Conners, 2012).

Customer satisfaction is an important concept for companies. In higher education institutions customers are students and academic staff. The success of a university depends largely on their customers' success. Universities have limited financial resources and DL is a useful tool for universities about cost saving. However if its customers' satisfaction level is low in DL courses in comparison with other traditional courses, there are two choices for institutions. First, leaving the DL system and second is to solve students' problems in the DL system to provide academic and financial sustainability.

\section{References}

Aaker, D. A. (1991). Managing brand equity. New York: The Free Press.

Akeusola, O., Daniel, O., and lyere, T. (2011), Analytical studies of various marketing approaches that could assist the growth of educational programmes of the open and distance learning institutions. International Journal of Academic Research, 3(3), 700-705.

Alves, H. and Raposo, M. (2010). The influence of university image on student behavior. International Journal of Educational Management, 24(1), 73-85. 
Banas, E. J. and Emor, W. F. (1998). History and issues of distance learning. Public Administration Qurterly, 22(3), 365-383.

Beneke, J.H. (2001). Marketing the institution to prospective students - A review of brand (reputation) management in higher education. International Journal of Business and Management, 6(1),29-44.

Biel, A. L. (1992), How brand image drives brand equity. Journal of Advertising Research, 12, 612.

Borstorff, P. C., Lowe, S. K. (2007). Student perceptions and opinions toward e-learning in the college environment. Academy of Educational Leadership Journal, 11(2), 13-28.

Chapman, B.F., Henderson, R. G. (2010). E-learning quality assurance: A perspective of business teacher educators and distance learning coordinators. The Delta Pi Epsilon Journal, LII(1),16-31.

Faircloth, J. B., Capella, L. M., and Alford, B. L. (2001). The effect of brand attitude and brand image on brand equity. Journal of Marketing Theory and Practice, Summer, 61-75.

Gedviliene, G. (2010). Adult distance learning quality in university studies. Tiltai, 2, 133-143.

Granitz, N. and Greene, C. S. (2003). Applying e-marketing strategies to online distance learning. Journal of Marketing Education, 25(1), 16-30.

Grönross C. (1984). A service quality model and its implications. European Journal of Marketing, 18(4), 36-44.

Gruber, T., Fuß, S., Voss, R., Glaser-Zikuda, M. (2010). Examining student satisfaction with higher education services using a new measurement tool. International Journal of Public Sector Management, 23(2), 105-123.

Guha, A. S. and Maji, S. (2008). E-learning: The latest spectrum in open and distance learning. Social Responsibility Journal, 4(3), 297-305.

Güneş, A. and Altıntaş T. (2012). Evaluation of distance education components: A case study of associate degree programs. Academy of Educational Leadership Journal, 16(3), 23-34.

Henry, P. (2001). E-learning, technology, content and service. Education and Training, 43, 249255.

Jose, S., (2010). eLearning: A global strategic business report. Retrieved on 12 September 2012 from http://www.prweb.com/releases/elearning/corporate_elearning/prweb4531974. htm.

Judson, K. M., Aurand, T.W., Gorchels L., and Gordon G.L. (2009). Building a university brand form within: University administrators' perspectives of internal branding. Services Marketing Quarterly, 30, 54-68.

Jung, I. and Latchem, C. (2007). Assuring quality in Asian open and distance learning, Open Learning, 22(3), 235-250.

Jung, I. (2011). The dimensions of e-learning quality: From the learner's perspective. Education Technology Research and Development, 59, 445-464.

Kang, G. D. and James, J. (2004). Service quality dimensions: An examination of Grönrooos's service quality model. Managing Service Quality, 14(4), 266-277. 
Keller, K. L. (1993). Conceptualizing, measuring, and managing customer-based brand equity. Journal of Marketing, 57, 1-2.

Kotler, P. and Keller, K. L. (2012). Marketing management (14th ed.). Englewood Cliffs, NJ: Prentice Hall.

Kotler, P. and Fox, K. (1995). Strategic marketing for educational institutions (2nd ed.). Englewood Cliffs, NJ: Prentice Hall.

Kwek, C. L., Lau, T.C, and Tan, H.P. (2010). Education quality process model and its influence on students' perceived service quality. International Journal of Business and Management, 5(8), 154-165.

Lin, H.F. (2010). An application of fuzzy AHP for evaluating course website quality, Comput. Educ, 54(4), 877-888.

McNally, D. and Speak, K. (2002). Be your own brand: A breakthrough formula for standing out from the crowd. San Fransisco, CA: Berrett-Koehler.

Nunnally, J. (1978). Psychometric theory ( $2^{\text {nd }}$ ed.). New York: McGraw-Hill.

Oldfield, B. M. and Baron, S. (2000). Student perceptions of service quality in a UK university business and management faculty. Quality Assurance in Education, 8(2), 85-95.

Pallant, J. (2005). SPSS Survival Manual A step by step guide to data analysis using SPSS for Windows (Version12). Sydney, Australia: Allen \& Unwin.

Parasuraman, A., Berry, L. L., \& Zeithaml, V. A. (1988). SERVQUAL: A multiple-item scale for measuring customer perceptions of service quality. Journal of Retailing, 64(1), 12-40.

Quilter, S. \& Weber, R. (2004). Quality assurance for online teaching in higher education: Considering and identifying best practice fore-learning. International Journal of $E$ learning, 3(2), 64-73.

Ruth, D. \& Conners, S. E. (2012). Distance learning in a core business class: Determinants of success in learning outcomes and post-course performance. Academy of Educational Leadership Journal, 16(1), 123-131.

Sheeja, S.R. (2011). Major trends and issues in the field of distance education. Indian Journal of Science and Technology, 4(3), 201-203.

Sizoo, S., Malhotra, N., Naveen, K., \& Bearson, J. M. (2003). Preparing students for a distance learning environment: A comparison of learning strategies of in-class and distance learners. Journal of Educational Technology Systems, 31(3), 261-273.

Sondoh, S. L., Omar, M. W., Wahid, N. A., Ismail, I., \& Harun, A. (2007). The effect of brand image on overall satisfaction and loyalty intention in the context of color cosmetic. Asian Academy of Management Journal, 12(1), 83-107.

Targamadze, A., Petrauskiene, R., \& Rubliauskas, D. (2010). Influence of technologies on quality of distance learning. Electronics and Electrical Engineering Informatics Engineering Sciences, 6(2), 131-134.

Tseng, M. L., Lin, R. J., \& Chen, H. P. (2011). Evaluating the effectiveness of e-learning system in uncertainty. Industrial Management \& Data Systems, 111(6), 869-889.

United States Distance Learning Association. (2012). http://www.usdla.org. 
Wang, J., Solan, D., \& Ghods, A. (2010). Distance learning success - A perspective from sociotechnical systems theory. Behaviour \& Information Technology, 29(3), 321-329.

Wong, W. T. \& Huang, N. T. N. (2011). The effects of e-learning system service quality and users' acceptance on organizational learning. International Journal of Business and Information, 6(2), 205-225.

Wu, W. \& Hwang, L. Y. (2010). The effectiveness of e-learning for blended courses in colleges: A multi-level empirical study. International Journal of Electronic Business Management, 8(4), 312-322.

www.beykoz.edu.tr

www.nces.ed.gov/

www.tuik.gov.tr/PreHaberBultenleri.do?id=10736

www.yok.gov.tr

Correspondence: Dursun Yener, Ph.D., Instructor, Beykoz Vocational School of Logistics, Kavacık Campus, Beykoz 34805, Istanbul, Turkey. 